\title{
Mathematical Creative Thinking Ability of Junior High School Students in Solving Open-Ended Problem
}

\author{
Herwinanda Trisnaning Damayanti ${ }^{1)}$, Sumardi ${ }^{2)}$ \\ 1) Undergraduate Student of Mathematics Education, Universitas Muhammadivah Surakarta \\ ${ }^{2)}$ Department of Mathematics Education, Universitas Mubammadiyah Surakarta \\ Corresponding author: sumardi@ums.ac.id
}

\begin{abstract}
The study aims to describe the ability of mathematical creative thinking on the aspects of fluency, flexibility, and originality in solving open-ended problem of Linear Equations with One Variable. The subjects are $7^{\text {th }}$ grade students of one private junior high school in Surakarta, Central Java, Indonesia. The data was collected by the test, interview, and documentation. The method of data validation was used triangulation, i.e. techniques and resources. The analysis technique of the data was used an interactive method that consists of the reduction, presentation, and conclusion. The result of the research shows that the fluency aspect achieved by the students ability to mention the possibility of other answers. Then, the flexibility aspect is showed by the students use different method to solve the problem, or at least use the appropriate method. The originality aspect is showed by the students" ability to make the problem which are rarely found by other students.
\end{abstract}

Keywords: creative thinking, open-ended problem, linear equations with one variable

\section{Introduction}

Mathematics is an important subject in education. It is widely used in many areas of life. According to Ibrahim and Suparni (2009) the purpose of learning mathematics is "to equip students with the ability to think logically, analytically, systematically, critically, and creatively" (p.36). Mathematics learning should be able to encourage students to learn meaningfully without overriding the abstractness of mathematics subjects. One of the goals of learning mathematics is to facilitate students with creative thinking skills. Creative aspects of the brain can help explain abstract concepts, thus allowing students to achieve greater mastery, especially in math and science subjects. Creative teaching has a role in improving the quality of education and enacting the meaningful learning (Yusron, 2011: 130).

Student's Mathematics achievement in Indonesia is still lower than the students in other countries. Kemendikbud (2006) reports the result of (PISA) in 2006 is still below the international average. Indonesian students are ranked 61 out of 65 countries. The underlying causes are lack of students' ability to solve non-routine or high-level problems. Moreover, the evaluation system in Indonesia apply low-level questions so that the students are accustomed to use formal knowledge to solve the problem.

Briggs and Davis (2008) argue that the creative thinking can be promoted by providing open ended problems. According to Becker and Shimada (1998), Open Ended 
Approach is a problem that is formulated to have the correct answer. The Aspects in open-ended approach can be classified into three types; 1) the process of solving the problem, that is a matter that has some ways to solve, 2) the result, that it has many correct answers, and 3) further development, that is when students have finished something, then they can develop new problem related to previous problem. The advantages of using open ended problems according to Becker and Shiamda (1998) are students more actively participate in learning, have opportunities to use knowledge and skills, can solve problems in their own way, and have motivation to provide the proof. The results of research conducted by Murni (2013) shows that the open-ended approach can facilitate students' courage to express their arguments and opinions in order to improve their thinking ability. The ability of mathematical creative thinking can be seen from measuring some aspects in solving the problem such as fluency, flexibility, and novelty (originality) (Becker and Shiamda, 1998). Therefore, the purpose of this study are to describe the ability of mathematical creative thinking of the junior high school students on the aspects of fluency, flexibility, and originality in solving open endedproblem of Linear Equation with One Variable.

\section{Research Methods}

This research was qualitative descriptive in nature by using purposive sampling. The subject was six students in grade VII in one of private junior high school in Surakarta, Central Java, Indonesia. The data was collected by using test, semi structured interview, and documentation. The test was used to obtain the data of creative thinking ability then following by semi structured interview to gain information of further students' mathematical creative thinking ability. The documentation was used to obtain the data about students' profile and answer sheet. In this research, 33 of $7^{\text {th }}$ grade students were given three open-ended problems related to Linear Equations with One Variable. Based on the test result, the students were grouped into three category of mathematics ability; high, moderate, dan low. Score and number of students of each group are presented in Table 1. Furthermore, on each category was chosen two students as subject of the research to interview.

Table 1.

Category of Students' Mathematics Ability

\begin{tabular}{ccc}
\hline Score & Category & Number of Students \\
\hline Score $>75$ & High & 6 \\
\hline $50 \leq$ Score $\leq 75$ & Moderate & 21 \\
\hline Score $<50$ & Low & 6 \\
\hline
\end{tabular}

\section{Results and Discussion}

The creative thinking ability of junior high school students in solving open endedproblems of linear equations with one variable would be analyzed on three aspects, i.e. fluency, flexibility, and originality. Fluency is related to student answers can be provided. Flexibility is related to mathematical ideas found by students while originality related to uniqueness the student ideas. Three aspects of mathematical creative thinking would be investigated from students' answer sheet in solving open-ended problem then followed by interview. 


\section{Problem 1.}

Adi bought some Naruto comic packages. Each package contains four comics. Adi got one comic free as birthday discount so he brought thirteen comics in total. Make a model a linear equation with one variable based on the previous problem and find five equivalent equation.

In the first problem, students are asked to create mathematical models related to the problems and make five equations that are equivalent to the mathematical model obtained. Therefore, the first problem contains three aspects of creative thinking, i.e. fluency, flexibility, and originality. The answer of the student with high mathematics ability is presented in Figure 1.

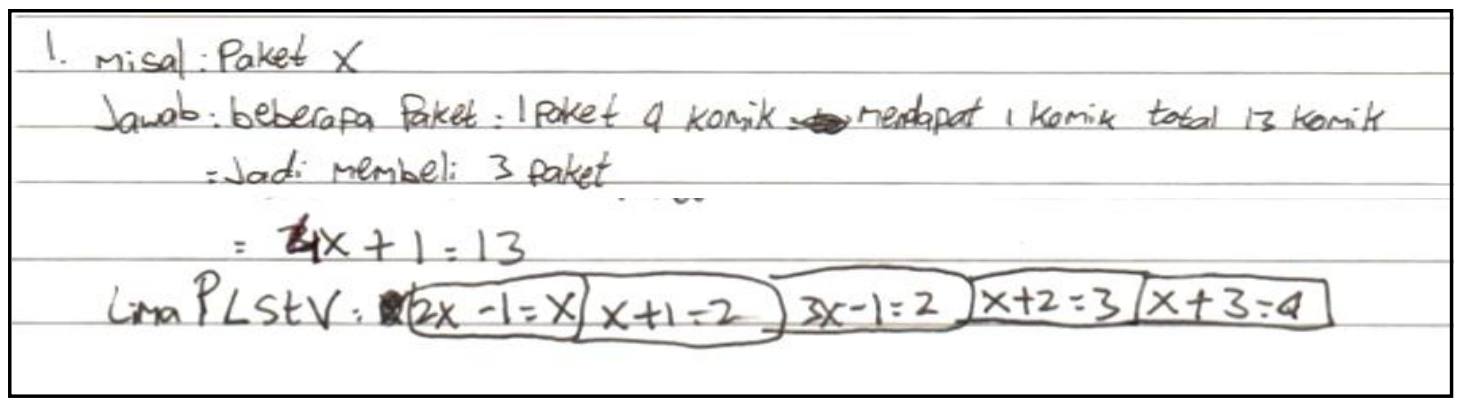

Figure 1. The answer of student with high-math ability on the first problem

Figure 1 showed that the student can provide a model of linear equations with one variable correctly. It was indicate that the student have the flexibility aspect that is he can write down what he is known, showed by using a variable $x$, then forming the equation model. During the interview, he can smoothly explain how to find the answer. Therefore, the student has been achieved the flexibility aspect although he only found one solution in constructing the equation model. This confirms the Mursidik study (2015) that the student with high-ability can generally solve open-ended problems in one true way as aspect of flexible thinking. Masruroh (2015) also concluded that the students with high math ability can write down information in the question correctly, no confusion in understanding the problem, telling the information and what the researcher asks, also explaining the problem with his own words.

In Figure 1, the student could not write the equations which is equivalent with mathematical model obtained. He wrote five equations but not equivalent with $4 x+1=$ 13. Hence, the student had not reached the aspect of fluency because he not able to provide an example of a linear equation with one variable equivalent to the equation model obtained previously. Bahar (2013) states that creativity and learning outcomes are two different things, especially thinking at a higher level. Student works closed problems usually cause difficulties in solving open problems. Basically, students will able to provide better examples of equivalent equations if students are accustomed to acquiring open questions. This is supported by Albert's (2013) opinion that providing an open mathematical problem will be more useful because it requires learning by collaborating knowledge rather than learning with application problems.

The students with high and moderate ability have the same characteristik in their mathematical creative thinking. In general, they could write down the mathematical model from the problem in the form of linear equation with one variable correctly. But, 
almost all of them could not write the equations which is equivalent with mathematical model obtained.

The students' answer with low mathematics ability is showed in Figure 2.

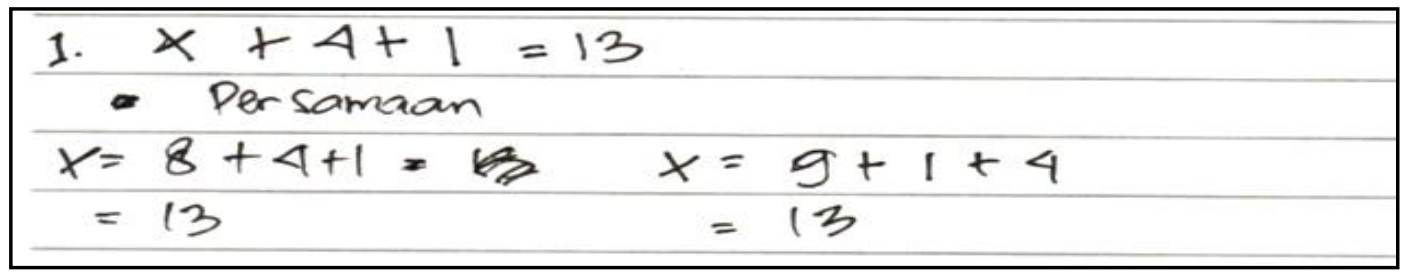

Figure 2. The answer of student with low-math ability on the first problem

Figure 2 showed that the student with low-math ability could not answer the problem correctly. He could not create the mathematical model from the given problem appropriately. He add $x$ with 4 because every package consist of 4 comics. It showed that the student did not understand yet how to make a model of linear equation. So, he has not been achieved the aspect of flexibility. In the interview, the student explain that he feel hard and confuse while working on the problem. He also could not find an equivalent equation with the mathematical model obtained. He did not know the concept of equivalent equation. This shows that he did not reached the fluency aspect. Therefore, the student with low math ability is not perform in mathematical creative thinking appropriately, especiallya on the flexibility and fluency aspects.

Accordingly, Putri (2015) states that the characteristics of students who cannot see the flexibility aspect such as students cannot find another solution and less conscientious in solving the open ended problem. Flexibility criteria are not fulfilled because students cannot solve problems in different ways. Students also do not meet the criteria of novelty because students cannot answer the problem in unusual ways.

On the other hand, students' answers in solving open ended problems is diverse. This is in accordance with Siswono (2011) opinion that students have diverse backgrounds and different abilities. They have diverse thinking, so their creative thinking also different. Students may be able to achieve three aspects, two aspects or one aspect.

\section{Problem 2.}

A fish has three of body part: head, body, and tail.

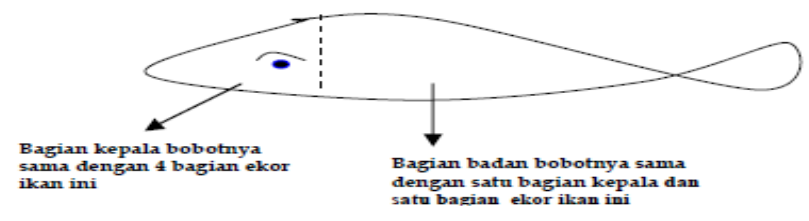

a. How many kilograms does the fish? write down the way to solve problem.

b. Examine the solutions. Elaborate at least two alternative solutions.

c. Write at least two problem on $24 \mathrm{~kg}$ fish.

On the second problem, the students were challanged to answer the problem which is contains of flexibility aspect (2.a and 2.c) and fluency (2.b). The answer of student with high mathematics ability on the second problem is showed in Figure 3. 


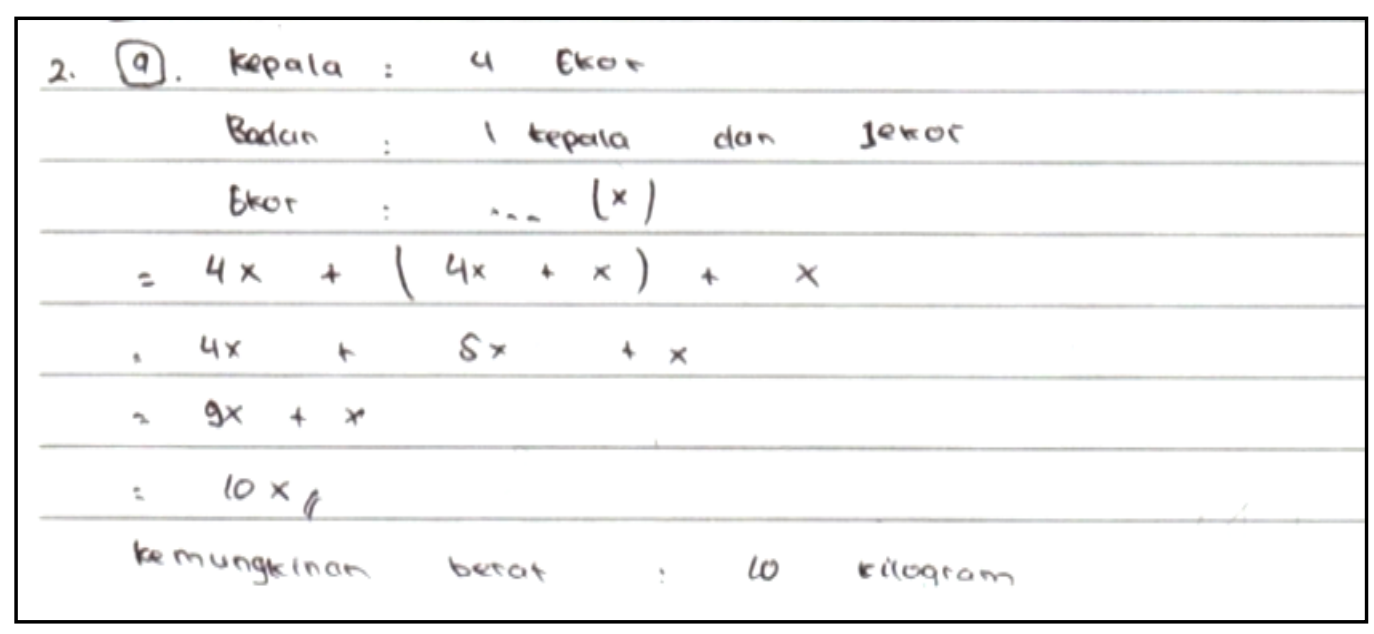

Figure 3. The answer of student with high-math ability on the problem of 2.a

Figure 3 showed that the student with high math ability can achieve flexibility aspect in solving the problem. The student is able to write down the information, calculate in detail and obtain correct solution. Another alternative to obtain the weight of fish is also obtained by the student. Although the way used had not been diverse but already can use two different ways. He could mention also other fish weight possibilities. The achievement of flexibility aspect was seen clearly during the interview process. He fluently explains how to obtain the weight of the fish.

\begin{tabular}{|c|c|}
\hline Resea & how do you calculate the weight of the fish? \\
\hline Student & $\begin{array}{l}\text { replace the part of body fish Mom, fish tail, head, and body, } \\
\text { find the total weight, I add them. }\end{array}$ \\
\hline & If the fish has $10 \mathrm{~kg}$ of weight, how many $\mathrm{kg}$ is the fish tail? \\
\hline & $1 \mathrm{~kg}$ Mom. \\
\hline
\end{tabular}

Accordingly, Murni (2013), the open-ended approach can provide students with the opportunity to gain experience, knowledge, and solve problems using a variety of ways. Furthermore, Fardah (2012) also concluded that students with high thinking ability will produce creative thinking products covering various categories, different responses generated when compared with other students. The results given are detailed and clear.

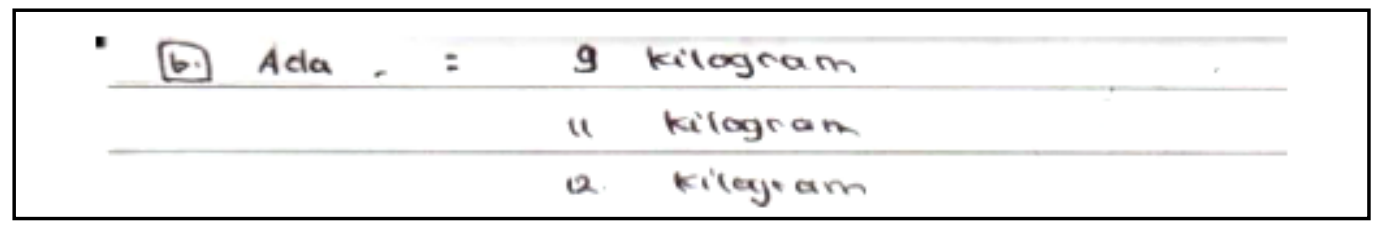

Figure 3. The answer of student with high-math ability on the problem of $2 . b$

In Figure 3, the student presented three examples of the possible weight of the fish. He wrote $9 \mathrm{~kg}, 11 \mathrm{~kg}$, and $12 \mathrm{~kg}$ as the alternative solution. Unfortunately, he did not explain the other alternative of weight. The students' answers indicated that he had ben achieve the fluency aspect of mathematical creative thinking. The interview with the student showed the achieving of fluency aspect of the subject in solving the second problem. 
Researcher : Is there other possible weight of the fish?

Student : Yes, a lot Mom.

Researcher : How do you know?

Student : Weight of the tail is diverse. So, the weight of fish also diverse

On the Problem 2.c, the student with high mathematics ability made a problem by using mathematical models that have not been appropriate. This is in line with Siswono's argue that there are students with high level creative thinking ability level but has difficulty in making suitable problem than solving given problem. It happen because students are rarely faced on this instruction. High-ability students encouraged to make the appropriate problem carefully based on instruction given.

The student with average mathematics ability is having difficulty in solving problem 2 as shown in Figure 4. He has not been precise in representing weight of the fish.

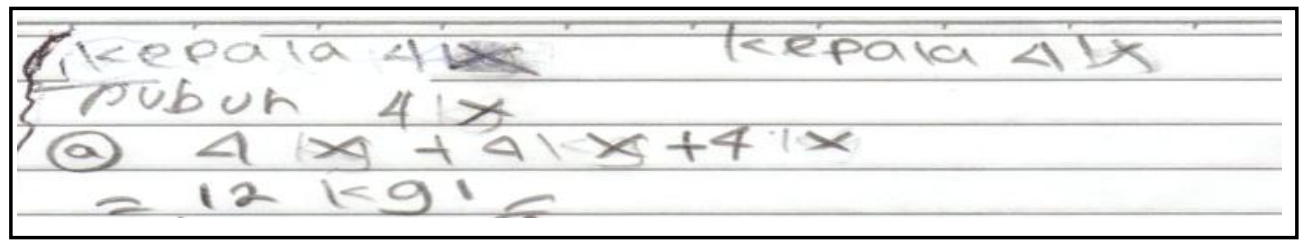

Figure 4. The answer of student with moderate-math ability on the second problem

Based on the interview, the student felt confused when given open problems.

Researcher : how do you solve the problem 2?

Student : I feel confused, Mom.

Researcher : which one do you confuse?

Student : there is information that the head has 4 times weight of fish tail, but there is no information on fish tail weight?

The difficulties in solving open-ended problem also shown in students with low mathematics ability as presented in Figure 5.

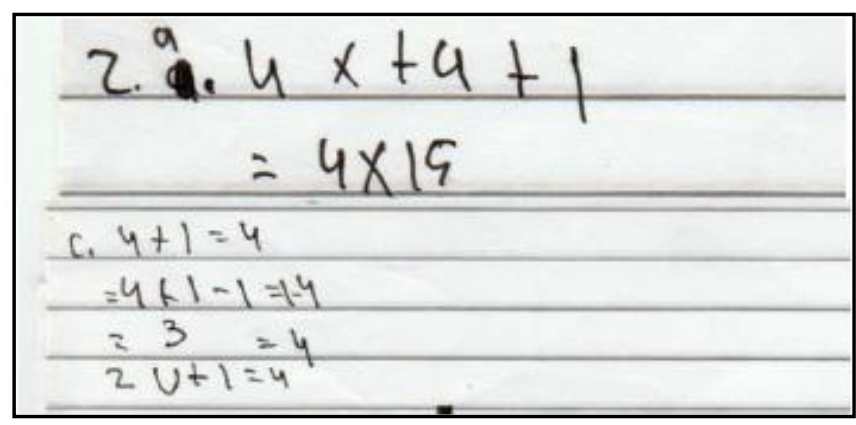

Figure 5. The answer of student with low-math ability on the second problem

Figure 5 showed that the student did not understand the problem appropriately. His answer was irrelevant with the questions in the second problem. It was indicate that he did not achieve yet the flexibility aspect on mathematical creative thinking. 


\section{Problem 3.}

Koko wants to do an experiment about balance. There are 10 pieces of iron balls and 2 pieces of iron plate. One iron balls weighs $1 \mathrm{~kg}$, but the weight of the iron plate is unknown. Curious to know how heavy the iron plate, Koko perform experiments as follows.

- In the first experiment, 1 piece of iron plate plus 1 iron ball balanced with 4 pieces of iron balls.

- In the second experiment, 1 piece of iron plate plus 2 pieces of iron balls balanced with 5 pieces of iron balls.

- Determine the weight of the iron plate, and write down the possibilities of another experiment!

On the third problem, the students are asked to determine the weight of the iron plate and write down the another experiment. So, the problem contains two aspects of mathematical creative thinking, i.e. fluency and originality. The answer sheet of student with high mathematics ability is shown in Figure 6.

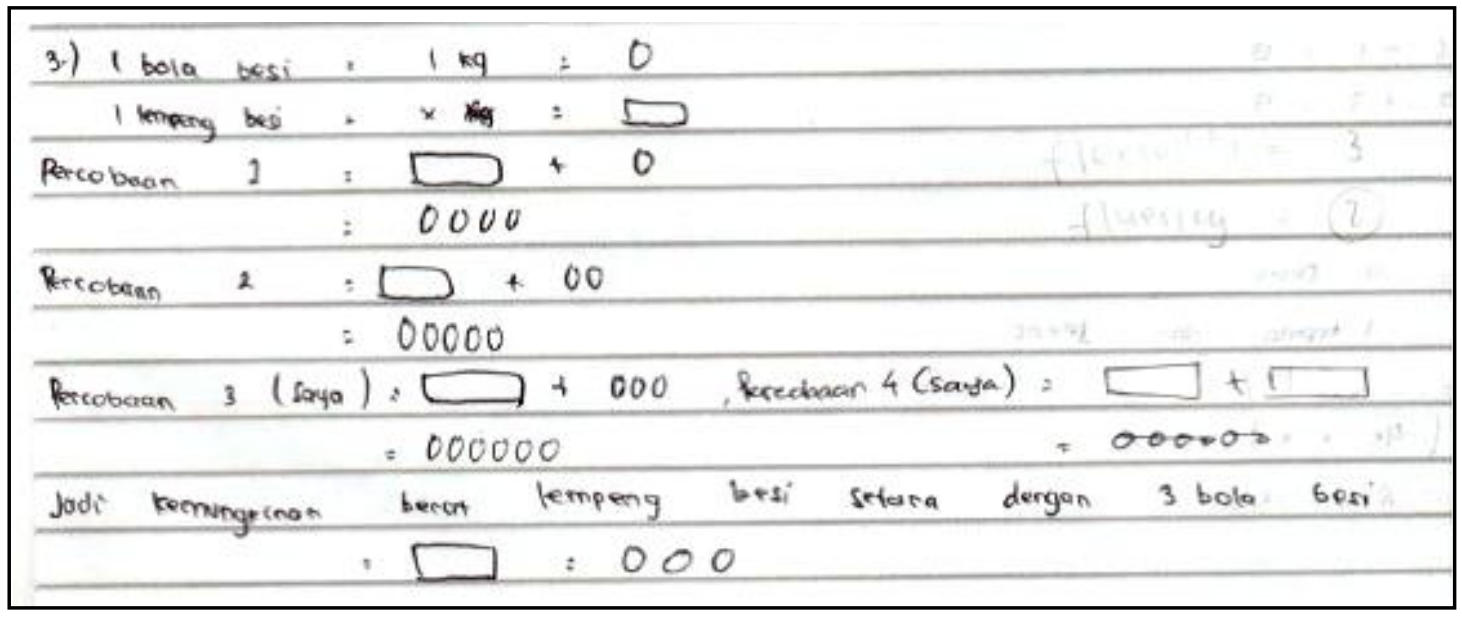

Figure 6. The answer of student with high-math ability on the third problem

Figure 6 showed that the student has been able to write down the possibility of other experiments of iron plate and ball so that it can be balanced. He provided more than one correct answer. The steps used was different from the others. He subtitute an iron plate with a rectangle and an iron ball with a circle. Based on illustration presented, he concluded that the weight of one iron plate equal to three iron balls. Therefore, he could achieve the fluency aspect on mathematical creative thinking. Based on the Figure 6 , the student has also achieved the aspects of originality because he was able to provide different answers. He used two iron plates in the answer, while only one plate in the examples. During the interview, he could explain another possibilities experiment with iron plate and balls.

Researcher : how do you solve the problem 3?

Student : first, I suppose the weight of the iron plate because it is not known

Researcher : and then?

Student : Determine the weight (the iron plate), $3 \mathrm{~kg}$

Researcher : Could you find the another experiment to keep balanced? 
Student : Yes Mom, I have written it (in the answer sheet)

Researcher : Is there another possibilities?

Student : Actuallay, there are many possibilities experiments

Researcher : How do you determine that it was balanced?

Student : The weight of plate is $3 \mathrm{~kg}$, so we could trial and error. For example, four balls were added with one plate equal to seven balls

Based on the answer sheet and interview, it can be concluded that the students with high mathematics ability had achieved the fluency and originality aspects in solving problem 3 .

The answer of student with moderate mathematics ability is shown in Figure 7.

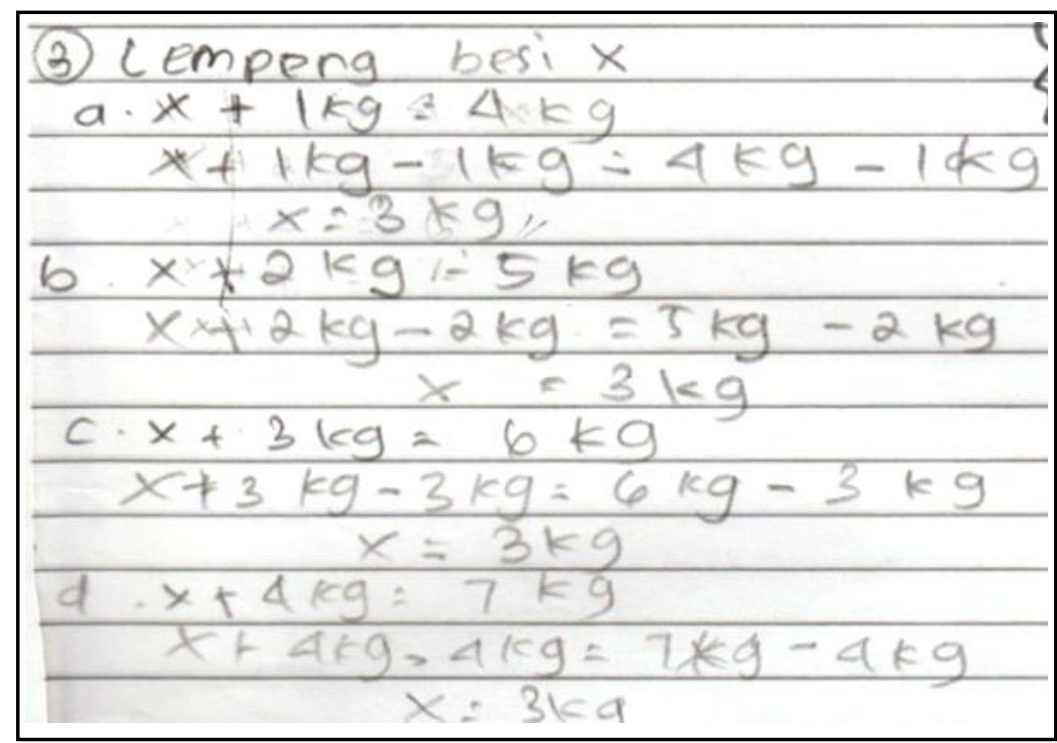

Figure 7 . The answer of student with moderate-math ability on the third problem

Figure 7 showed that the student could written the another possibilities experiments with iron plate and balls. In the first experiment, he added the iron plate with a ball. Next, he added one ball on each experiment. Therefore, the student has been achieved the fluency aspect on mathematical creative thinking. However, the possibilites experiments which the student made is still similar as presented in the example. He only added a ball on each experiments. He has not been able to use the iron plate to modify the experiment. So, the student has not reached the aspect of originality.

As shown in solving the first and second problems, students with low mathematics ability also can not achieve the fluency and originality aspects in solving the third problem. He could understand that the weight of an iron plate and a ball are $3 \mathrm{~kg}$ and 1 $\mathrm{kg}$ respectively. However, he did not understand how to make possibilities experiments using those iron plate and balls.

A similar study was conducted by Masruroh (2015) that the ability to think creatively on the fluency aspects of high and medium-skilled students was not much different, but still superior to students with high initial ability. It is seen in this research that the student with moderate mathematics ability can use its own knowledge in solving the problem. This research is also in line with Mursidik (2015) who claims that the student with medium category has reached in the aspect of good thinking because he can bring up one idea in solving the open-ended math problem. In the flexible thinking 
aspect, the students are also on good criteria. It means that he able to determine one way in solving open-ended math problems.

Furthermore, Anggraeny (2015) states that the aspect of originality can only be achieved by some students. Among the three aspects of creative thinking ability, the aspect of originality is the least achieved. In this study, it is quite difficult to get students who achieve aspects of originality. Only students with high mathematics ability can achieve that aspect even though they are not maximized. This is supported by Akgul (2016) which states that the relationship between the aspect of originality with the ability to think creatively was very close. So, the students who have been able to achieve the aspect of originality is already possible to achieve the level of creative thinking.

\section{Conclusion}

Firstly, the fluency aspect can be achieved by students with high and moderate mathematics ability. The students could mention more than one answer and made the conclusion correctly. In addition, they also can provide an example of other experiments in order to keep the balance. In contrast, the fluency aspect can not be achieved by students with low mathematics ability of all problems.

Secondly, the flexibility aspect can also be achieved obly the students with high and moderate mathematics ability. The student can explain how to find the model of linear equation with one variable and can give the appropriate reason. They can also explain how to obtain the weight of fish clearly and able to use different ways to obtain the weight of all fish. On the other hand, students with low mathematics ablity could not achieve the flexibility aspect at all problems because they can not solve any problem correctly.

Thirdly, the originality aspect can only be achieved by students with high mathematics ability. Students could come up with the idea of conducting another experiment using two plates while other did not. Students with high mathematics ability can also construct problem on $24 \mathrm{~kg}$ weight fish more vary even though less complete.

\section{Bibliography}

Akgul, S., \&Kahveci, N.G. (2016). A study on the development of mathematics creativity scale. Eurasian Journal of Educational Research, 6(2), 57-76.

Albert, L.R., \&Kim,R. (2013). Developing Creativity Through Collaborative Problem Solving. Journal of Mathematics Education at Teachers College, 4(2), 32-38.

Anggraeny, D.B., Siswono, T.Y. (2013). Identifikasi Tingkat Berpikir Kreatif Siswa Menggunakan Multiple Solution Task (MST). Jurnal Math Edunesa, 1(2)

Bahar, K.A., Maker, C.J. (2011). Exploring the Relationship Between Mathematical Creativity and Mathematical Achievment. Asia-Pasific Journal of Gifted and Talented Education, 3(1), 33-48.

Beetlestone, F. (2011). Strategi Pembelajaran untuk Melesatkan Kreatifitas Siswa. Diterjemahkan oleh: Narulita Yusron. Bandung: Nusa Media.

Briggs, M., \& Sue, D. (2008). Creavite Teaching Mathematics. New York: Routledge.

Fardah, D.K. (2012). Analisis Proses dan Kemampuan Berpikir Kreatif Siswa dalam Matematika Melalui Tugas Open-Ended. Jurnal Kreano, 3(2).

Fatah, A., et al. (2016). Open-Ended Approach: An Effort In Cultivating Students' Mathematical Creative Thinking Ability and Self-Esteem In Mathematics.Journal on Mathematics Education, 7(1), 11-20.

Ibrahim \&Suparni. (2009). StrategiPembelajaranMatematika. Yogyakarta: Teras. 
Kemendikbud. (2006). Survei Internasional PISA. Diakses 3 Oktober 2016: (http://litbang.kemdikbud.go.id/index.php/survei-internasional-pisa).

Masruroh, R., Sijado, I., \& Sari, D.R. (2015). Kategori Berpikir Kreatif Siswa Kelas VII SMP Negeri 1 Surakarta dalam Menyelesaikan Masalah Matematika pada Materi Pokok Himpunan. Jurnal Elektronik Pembelajaran Matematika, 3(3), 305-312.

Murni. (2013). Open Ended Approach in Learning to Improve Student Thinking Skill in Banda Aceh. International Journal of Independent Research and Studies, 2(2), 95-101.

Mursidik, E.M., Samsiyah, N., Rudyanto, H.E. (2015). Kemampuan Berpikir Kreatif dalam Memecahkan Masalah Matematika Open-Ended Ditinjau dari Tingkat Kemampuan Matematika pada Siswa Sekolah Dasar. Journal Pedagogia, 4(1), 23-33.

Putri, V.S.R., \&Wijayanti, P. (2013). Identifikasi Tingkat Kemampuan Berpikir Kreatif (TKBK) Siswa dalam Menyelesaikan Soal Open Ended pada Materi Segiempat di Kelas VIII SMP. Jurnal Math Edunesa, 2(2).

Shimada, Shigeru \& Jerry P. Becker. (1998). The Open-Ended Approach: A New Proposal for Teaching Mathematics. Virginia: National Council of Teachers of Mathematics.

Siswono, T.Y.E. (2011). Level of Student's Creative Thinking in Classroom Mathematics. Journal Educational Research and Review, 6(7), 548-553.

Siswono, T.Y.E. (2015). Desain Tugas untuk Mengidentifikasi Kemampuan Berpikir Kreatif Siswa dalam Matematika Diakses dari https://www.researchgate.net/publication/242735927 Desain Tugas untuk M engidentifikasi kemampuan berpikir Kreatif Siswa dalam Matematika

Sugiyono. (2012). Memahami Penelitian Kualitatif. Bandung: Alfabeta. 